\title{
Title - Armed Conflict and Human Trafficking in Nepal
}

\author{
Ms. Sadhna Mishra \\ (Research Scholar, Dept. of Political Science, Banaras Hindu University, India)
}

\begin{abstract}
It is well known that the armed conflict in Nepal is leading to serious threats in the lives of women and girls. They face various kinds of violence, discrimination and exploitation not only during the armed conflict but also during the post conflict and transition period. The trafficking of women and girls from Nepal to India and other likelihood the Gulf States remain high. The conflict of Nepal has increased the number of women working as prostitutes in Kathmandu and other area and this leads cross-border trafficking. The paper aims to find out the reasons responsible for women and girl child trafficking in Nepal during Maoist insurgency (1996-2007) and post-conflict situation as well. The present paper analyzes that how armed conflict negatively affect the lives of women in Nepal and also analyzes the impact of laws and polices instigated by the government of Nepal to combat human trafficking and lastly this paper gives some suggestions to combat Human Trafficking in Nepal.
\end{abstract}

Keywords: Armed conflict, Human Trafficking, Women, Policies, Nepal.

\section{INTRODUCTION}

War has been a central feature of human history, but in the contemporary world the character of war has been changed. This has meant that wars between the states have become much more unlikely than in previous era, but inter-state conflict has become more prominent, which increases political violence. Nepal is one of the examples of this political violence. Nepal has recently come out of a violent conflict of Maoist against the state during 1996-2006. The ongoing conflict was shifted into peace process after signing of the Comprehensive Peace Agreement between Six Party Alliance (SPA) and the Communist Party of Nepal (CPN)Maoists. Women and girl child trafficking is the third largest crime in the whole world and it is worldwide evil which is faced by many developing and developed countries. According to United Nation report of Trafficking in Person (TIP), 2012 around 2 crore 40 lakh peoples are the victim of human trafficking yearly and $80 \%$ of are the victim of sexual bondage, $17 \%$ of forced labour and 2 victims among 3 are women and 1 out of 100 are rescued from trafficking [1]. This data show that human trafficking is the major challenge for whole world. It is a severe problem for those countries that face socio-economic transformation. Most of the South- Asian countries like Nepal, Pakistan Bangladesh, where this problem has become more prominent. Nepalese young girls trafficked in different part of India like Siliguri, Kolkata, Patna, Guwahati, Jaipur, Delhi Agra,, Mumbai, Chennai and Bangalore etc.

Nepali women have been extremely affected by this armed conflict, and, as with many other conflicts. They face various kinds of violence, discrimination and exploitation not only during the armed conflict but also during the post conflict and transition period. In these various forms of violence, especially the acts of sexual exploitation, targeting women and girls enhance during the time of armed conflict [2]. Human Trafficking especially of women and girl child is another type of violence which is mainly faced by Nepali women. According to Human Trafficking Assesment Tool Report for Nepal, 2011 there is trend of trafficking of girls and women in China, Hong-Kong and Tibet for sexual exploitation [3]. Many young girls and women being trafficked to South-Africa as dancer and South Korea for the purpose of false marriages to Korean men, because Korean government adopts pro-natalist population policy, which encourages Korean people to give birth of children because birth rates of Korea are declining and Korean women don't want to have birth that's why Korean men get married to foreigner girls especially to Nepali girls [1]. According to UN news centre, 2010 approximately 10,000 children became victim of trafficking for military purpose and treated as child soldiers in the Maoist army. Around 1,000 to 2,000 children are working in the circuses in which $90 \%$ of them are girls and $10 \%$ are boys [4].

It is necessary to define Human Trafficking because there is confusion between migration and trafficking. Most of the definition of trafficking incorporates practices like abuse, deception, coercion, exploitation, use of threat, slavery and forced labour. In 2000 a report on trafficking submitted by UN Special Rapporteur on Violence against Women to the Human Rights Commission stated:

"At the core of any trafficking definition must be the recognition that trafficking is never consensual. It is the non-consensual nature of trafficking that distinguishes trafficking from other forms of migrations. The lack of 
informed consent must not be confused with the illegality of certain forms of migration. While all trafficking is, or should be, illegal, all illegal migration is not trafficking. It is important to refrain from collapsing the concepts of trafficking and illegal migration." [5]

Therefore, UN Special Rapporteur on Violence against Women formulates a new definition of trafficking which consists following feature:

- Trafficking is not limited to the cross border movement of person. It takes place both within and outside the nation.

- According to new definition women and girls have moved in an unfamiliar environment within and outside the nation, so that they disconnected from their physical and emotional support.

- There is chain of trafficking process. At the beginning of the chain there is seller of trafficked person and at the end of the chain there is receiver of the trafficked person, who holds his or her in forced labour and abusive condition and gets profit from that labour.

- Although numerous abuses may happen in the process of migration, the definition recognizes that complete chain process - from coerced transport to the coerced end-practice - that makes trafficking a distinct violation.

Traditionally, trafficking was understood as kidnapping and incarceration of workers - usually women and girls in the commercial sex industry, but recently the term trafficking have adopted broader definition addressing both working conditions as well as how a person is recruited or treated at a ensuing stage. This is reflected in the definition adopted by the United Nations Protocol on Trafficking ;

"Trafficking in persons shall mean the recruitment, transportation, transfer, harboring or receipt of persons, by means of the threat or use of force or other forms of coercion, of abduction, of fraud, of deception, of the abuse of power or of a position of vulnerability, or of the giving or receiving of payments or benefits to achieve the consent of a person having control over another person, for the purpose of exploitation. "[6]

According to the UN protocol there are three element of Human Trafficking: First, an action of trafficking such as transportation, recruitment, transfer, harbouring etc. Second, a means of trafficking such as force, coercion, deception, fraud, abuse of power and third, a purpose of exploitation.

This definition is suitable for South Asian countries like Afghanistan, Bangladesh, Nepal, Pakistan, Sri Lanka and India. Approximately 8 million people are trafficked across national border annually in which 80 percent of transnational victims are women and most of them are for commercial sexual exploitation. This figure is definitely frightening and need to be addressed with priority in policy, program and action by the world community [7]. In this perspective, a considerable attention must be given to cope with this major challenge.

The Specific Objectives Of The Study Are As Follows:

- To examine the linkage between armed conflict and women \& girl child trafficking in Nepal.

- To examine the connection between foreign labour migration and trafficking.

- To find out the reason for human trafficking in Nepal during conflict.

- To critically examine the policies, laws and government's commitments to combat trafficking.

\section{METHODOLOGY}

The methodology of this paper is analytical, descriptive and required information's are collected from different secondary sources like books, research articles, and different government documents. The present study is based on the analysis of reports by international governmental and non-governmental organizations, newspaper articles and academic publications.

\section{Armed Conflict In Nepal: Background}

Nepal has been divided into five regions such as Far West, Mid-Western, Western, Central and Eastern Region and the country also divided into 75 districts and further these districts divided into small units known as Village Development Committee (VDC). In each region few district where Maoist camps are located such as Kailali in Far West region, Surkhet and Rolpha in mid-western region, Nawalparasi in Western region, Chitwan and Sindhuli Mandi in Central region and IIam in Eastern region. We can see these areas through this map. Map 1

The Ministry of Women, Children and Social Welfare (MoWCSW) identify 26 districts that are very prone to Human Trafficking, They are: Gorkha, Banke Udayapur, Rasuwa, Sindhuli, Jhapa, Ramechhap, Mahottari, Sarlahi, Dhanusa, Kailali, Kavrepalanchowk, Makawanpur, Nuwakot, Dhading, Sindhupalchowk, Lalitpur, Chitwan, Kaski, Morang, Sunsari, Rupandehi, Parsa, Kathmandu, Dang and Parsa [8].

The country reflects dual nature with urban area with modern facilities and opportunities and rural areas with fewer facilities and opportunities. The existing structural inequalities and socio economic condition provided a 
ground for Maoist which encourages ethnic groups, lower castes and women to take part in armed conflict. According to the Developmentalists Maoist movement of Nepal is basically a social and economic movement and it is the product of failed government. Factors like poverty, underdevelopment and unemployment contributed to enhance the insurgency in Nepal. Poverty is the main reason for Maoist insurgency in Nepal [9]. According to sociologist point of view the ethnic causes are responsible for people's war. In Nepal the 35 percent of total population are Hindus, Bramhin, Chhetri and Newar ethnic group and they have dominant position in power structure and other ethnic groups such as tribal and dalit are excluded from mainstream politics. Political scientists see the failed administration of Nepal is the prime reason for Maoist movement. After 1990s in the absence of stable constitution, king's affirmation for power, lack of strong leadership, split in inter party system, corruption etc. are another reasons for Maoist insurgency in Nepal. The structure of Nepalese society was a feudalistic, monolithic, repressive, authoritarian, centralised and closed state for centuries. Due to this characteristic of state the vast majority of Nepalese people eliminated from the nation building process and this became the root cause for the insurgency in Nepal [10]. The Maoist started People's War to remove the existing feudal socio-political structures production relations and they unite them as United People's Front (UPF). On the $4^{\text {th }}$ February 1996, the UPF submitted 40 point demand to the Prime Minister Ser Bahadur Deuba of the Nepali Congress government. They declared that if the government did not accept the demands then they started People's War but the government did not take demands seriously. Consequently, The UPF (Maoist) started a People's War on $13^{\text {th }}$ February 1996 which ends in 2006 after the signing of the Comprehensive Peace Agreement between Six Party Alliance (SPA) and the Communist Party of Nepal (CPN)-Maoist the ongoing conflict was shifted into peace process. In the violent conflict of Nepal the exact numbers of deaths are not known but according to Informal Sector Serve Centre (INSEC) there were 10,985 deaths and according to the Ministry of Peace and Reconstruction there were 16,278 deaths [11]. In the conflict women have became victim of the conflict and as well as they became agency for establish peace in Nepal.

\section{Women And Girl Child Trafficking During Conflict}

The trafficking of women and girls from Nepal to India and other likelihood the Gulf States remain high. Agencies like Save the Children and others have become more concerned about conflict-induced migration of women and girls within and outside Nepal; this led to high level of trafficking and commercial sexual exploitation. Maoist conflict of Nepal increases prostitution in army barracks and police posts. During the time of conflict in Nepal women and girls are kidnapped and enslaved by government and rebel forces. They are used as military sexual slaves. The kidnapped women face lots of social, economic and health problem after their release from the camps. The abduction and sale of women and girls has become an important source of income during conflict for war lords so they get lots of profit from women trafficking.

Due to the fear of armed conflict and in search of work and security Nepali women has to choose to work as prostitution in dance bars and further these women sent other countries for the purpose of prostitution. There are high levels of demand of Nepalese girls for prostitution because of their beauty. American and European agencies reported in 2003 that around 2, 00,000 - 3, 00,000 Nepali girls and women engaged in prostitution in India [12]. According to a Nepalese NGO approximately 2, 00, 00 Nepali girls forced to work as sex worker in India. If we analyze the dimensions of the trafficking in Nepal, we find that there are two types of trafficking, first internal trafficking and second, cross-border trafficking. According to Nepal's National Report on Trafficking (2006-2007), trafficking in girls and women in Nepal is associated with the Nepalese feudal and patriarchal social structure. Therefore the forms of trafficking are being transformed with the changing sociopolitical situation of Nepal [7]. Historically, during the Rana regime (1847-1951) girls were recruited in Kathmandu palaces for the purpose of labour \& entertainment and these girls were brought from the surrounding Kathmandu valley. They worked as housemaid, dancer, and singer. This is the example of internal trafficking. In the post Rana regime and panchayat period (1960-1990) the cross- border trafficking has started for the purpose of sexual exploitation. In mid 1990s-2006 Nepal has faced violent armed conflict and during the period of conflict both internal and cross-border trafficking has been occurred for the purpose of foreign labour and sexual exploitation. The following table shows different dimensions of the trafficking in Nepal.

Table 1

\subsection{Armed Conflict and Internal Trafficking}

The armed conflict of Nepal initiates the mass displacement, kidnapping and killings, especially from the state side. The conflict has heightened displacement of thousands of people caught between the Maoists and the security forces and they called Internally Displaced Person's (IDPs) [13]. Women and girls left their home in search of security and livelihood so they were become more susceptible to being trafficked. They forced to leave their habitual homes from Maoist and military of the state as well. A huge number of civilians are being displaced due to fear of being forcibly recruited in Maoist armed forces because according to the Maoist policy one person from each household must join the Maoist armed forces and if this not happens then their families 
are tortured by them. In $1995^{\circ}$ Operation Romeo', launched by the state in Rolpa district of Nepal, and about 6,000 people have been forced to leave their homes in search of security. During the conflict period, so many Nepali organizations and institutions who involved in rehabilitation programs for IDPs, they ranged approximately 30,000 to 500,000 IDPs [14] and these numbers increases from 2007 onward when madhesi peoples started protest over the lack of progress in the implementation of the peace process. So this violence forced thousands of people to leave their homes [15]. Many IDPs identified as anti-state so if these IDPs crossed Nepali borders, they took under the category of refugees. According to a study on the one hand people have to face massive brutality and arbitrariness of the police and on the other side they face Maoist terror. The police come to the people's home and ask about the Maoist and then Maoist come and ask why the police came? Therefore, in this atmosphere of terror the men have escaped from their house and left behind their wives and children. Thus, some villages in the western hill districts of Nepal, there are no men. In these villages women forced to leave their home [16]. In 2002, the numbers of Internally Displaced Persons (IDPs) were estimated in between 100,000 and 150,000 [17] and in 2005, the number was approximate to be in the range of 180,000 to 231,000 [18]. Most of them are forced to live in the streets, temple grounds, or find work as domestic helper or other forms of labour. In such situation, they are easy targets for sexual and other forms of exploitation. Conflict has increased the number of women working as sex workers in Kathmandu and in Nepali border area; they commenced playing in dance bars as dancers and sex workers. This increased the cross-border trafficking but there is less evidence that women working as sex worker had been trafficked [7].

This is the fact that during conflict women were abducted by government military forces and paramilitary of rebel militia for sexually servitude and enforced military prostitution. These women were kept in comfort stations organised by the military leadership and these women were raped and tortured by high ranking members of the military. In many cases these abducted women are married to military men.

\subsection{Armed Conflict and Cross-Border Trafficking}

There is necessity for war lords to get source of income for running war. Thus, for the purpose of prostitution and foreign labour women and girls were sent to overseas. So many studies revealed this truth that there are five major region for trafficking [19]. They are - India, Gulf Countries, East and South Africa, Europe and Australia, North Amarica. There are three Indian sectors where the vulnerability of trafficking is high. These are - private sector such as agriculture sector, industry, and construction work etc., second public sector such as Indian Army and police and third undesirable sector such as commercial sex industry. According to ILO report 29 districts of Nepal have high occurrence of trafficking, whereas, UNIFEM identifies 39 districts as vulnerable compared to 26 identified by government of Nepal [20]. Nepal have open border with India therefore most of the women and children has been sent to India. Approximately 5,000 - 15,000 women and girls are trafficked annually to India for the purposes of commercial sexual exploitation [1] and according to ILO/IPEC Rapid Assessment, 2001 about 12,000 children below 18 years are trafficked annually to India [21]. Labour Trafficking is another type of trafficking which arises in Nepal. Due to socio-economic-political situation of armed conflict the possibility of foreign labour trafficking has also increased. Now, the victims of trafficking are not only children and women, but they are also men. The flourishing of carpet industry in Nepal induces the women and child trafficking. Poor and rural women provided cheap labour for the industry and because of their expertness their demand has high in abroad [22]. A large number of boys and girls were trafficked to Indian carpet factories such as Bhadohi and Mirjapur of Baranas district [7].

\section{Human Trafficking Laws And Policies: An Analysis}

Human Trafficking is the major challenge in front of Nepal Government, so with this respect Nepal government adopted number of programme to combat human trafficking. Nepal has showed international commitments which are relevant to human trafficking such as Vienna Convention (1993), which consider human trafficking as gender-based violence, Copenhagen Declaration on Social Development (1995), it calls on governments to take effective measures against traffickers, Beijing Platform of Action (1995), it urges governments to build effective networks to dismantle trafficking networks and to design programs for providing rehabilitation to the trafficked victims [7]. Unfortunately, these conventions, plan of actions are not binding under the international law. Therefore it depends on Nepal government whether they fulfil their international commitments or not. Nepal has also made some policies, institutional arrangements and programs to combating human trafficking. During 1997-2002 Nepal has adopted three major strategies related to women welfare: gender mainstreaming, eliminating gender inequality and empowerment. In this process government amended Muluki Ain (the country's civil \& criminal code). According to new Muluki Ain no one shall take anybody out of Kingdom of Nepal for the purpose of sale but this provision does not prohibit the sale of human being within the territory of Nepal so it does not prohibit internal trafficking [22]. In 1995, the Government of Nepal adopted 13 point policies on combating trafficking and in 1998 the Government formulated NPA against Trafficking in Children and Women for Sexual and Labour Exploitation and it were revised in 2001. The NPA has identified 
some areas of action. They include: policy, legislation, awareness, health and education, employment, rehabilitation related to trafficking [1]. Nepal has adopted Trafficking in Human Beings (Control) Act, 1986 and this Act says that any person residing outside of Nepal who commits any act punishable under the Act should be brought in action under the Act. A new anti-trafficking Bill Trafficking on Human Beings (Act) has been introduced in 2002 and this bill has proposed for the criminalization of prostitution.

Nepal has propagated Human Trafficking and Transportation (Control) Act 2007 (HTTCA) and Human Trafficking and Transportation (Control) Rules, 2008 (HTTCR). The HTTCA prohibits internal as well as external or cross-border trafficking in persons and also prohibit sex and labour exploitation, but this law fails to tackle issues like witness protection and border measures. Nepal has enacted the Act Made to Armed and Consolidate Laws Relating to Foreign Employment (Foreign Employment Act, FEA) of 2007. This Act is guaranteed Foreign Employment is secure and decent.

Nepal also creates an office known as Office of Special Rapporteur on Trafficking, which monitor the cases of trafficking in Nepal and publish annual report on trafficking. Nepal has trying to tackle this problem with international collaboration. For example Nepal is a member of SAARC convention on Trafficking in women \& children and Nepal has signed four bilateral agreements with Bahrain, Qatar, South Korea and UAE. epal has taken in close to institutional arrangements for combating trafficking, such as Ministry of Women, Children and Social Welfare (MoWCSW), Central Child Welfare Board (CCWB), District Child Welfare Board (DCWB) and Social Welfare Council (WSC) are a substantial organization in this context. The ONRT-NHRC is an independent body to monitor the trafficking situation. The major drawback of Nepal's government polices is that there is no specific law that deals with migration and the protection of the rights of migrant labourers. Nepal has no unified database system for monitoring anti trafficking activities and situation of trafficking in persons and there is very little coordination between the various governmental organizations as MoWCSW, the National Committee including NHRC etc.

\section{Trafficking Of Women In Post-Conflict Situation In Nepal}

It is said that if the roots of the problem are very strong then it is difficult to end the problem properly. It is right in the case of Nepal's human trafficking problem. After the end of Maoist conflict in Nepal the problem of human trafficking still creating problem for the society of Nepal. The post conflict society can be areas of the origin of trafficking. After the end of conflict, there is high level of political instability in the society and in this situation there are high chances of criminal activity like trafficking. In Nepal former militia, war lords and ex-combatants may turn to Human Trafficking as a means to replace revenue losses caused by the end of the war. Besides this, former traffickers have become more rich during the war may try to use politicaleconomic influence in the political-economic rebuilding processes of a region. Secondly, if we think about postwar socio-economic condition of the society then we will found that the situation of post war period is similar to the war period. Because of weak economic situation of women in post conflict period in Nepal, women are high vulnerable to being trafficked into military prostitution. Women and girls are still living in poor livelihood condition, they have lack of economic opportunities and they still living in an insecure atmosphere. In this condition women and girls were trafficked to other countries in search of livelihood. Women who released from military camps are vulnerable to being trafficked.

According to Nepal's National Human Rights Commission (NHRC) approximately 5,210 women and children were trafficked in the year 2009-2010 and among them 1609 were intercepted from different border point, 207 were rescued, 112 were repatriated from the Gulf states and India and 365 were provided rehabilitation service [24]. Another report (Human Trafficking Assessment Tool Report for Nepal) said that between 5,000-15,000 women and girls trafficked yearly in India for the purpose of commercial sexual exploitation. This data clearly shows that the problem of Human Trafficking is still formidable challenge for Nepalese government [3].

\section{RECOMMENDATIONS}

Some Of The Recommendations Are As Follow:

- There must be general education for girls who generally migrate with less information and they have no idea where to go if they face trouble.

- There must be development programme for women especially because when they are in trouble they get income from other sources not from prostitution.

- The save migration programme must be introduced.

- There should be modification in border trafficking rule in Nepal.

- There must be create new jobs, if the government employing women in rural areas of Nepal then there is less chances to sell women in other countries.

- There should be started awareness campaign to let women and girls know about legal aspect of human trafficking. 
- There should be increased in penalties for those who involved in trafficking.

- There must be establishing a special investigation cell for human trafficking in Nepal.

- There must be coordination between different organization and NGOs such as MoWCSW, MoLE, MoFA, etc. who fighting for human trafficking problem.

- International Organization and NGOs and global funding agencies come forward and give financial support to the government of Nepal.

- There must be effective control of the government over monitoring system and funding system so that the misuse of funds can be checked.

\section{CONCLUSION}

In general, the trafficking of women during and post conflict period is similar to trafficking in general situation. But armed conflict gives amplification to these factors. Trafficking of women and children has become important part for war economies and for economic profit of the war lords. Thus, because of this region the sexual and labour exploitation of women and children be a part of military actions. On the other hand economic, political and social annihilation, loss of sources of life and personal experience of conflict raises women trafficking in Nepal.

In conclusion we can say that the socio-political-economic circumstances of Nepal during Maoist insurgency are the prime reason for human trafficking and conflict is significantly increased both internal and external trafficking. Due to the fear of armed conflict and in search of work and security Nepali women has to choose to work as prostitution in dance bars and further these women sent other countries for the purpose of prostitution. The conflict of Nepal has increased the number of women working as prostitutes in Kathmandu and other area and this leads cross-border trafficking in India and Gulf states. In all types of trafficking, the purpose of trafficking is sexual exploitation and labour exploitation. At last, whatever the policies and plans initiated by the Nepalese government are relevant to the problem but the implementation process of these policies are not up to the mark.

\section{REFERENCES}

[1]. ONRT, Trafficking in Persons Especially on Women and Children in Nepal, National Report 2011.( Kathmandu: ONRT/NHRC, 2012).

[2]. National Action Plan On Implementation of the United Nations Security Council Resolutions 1325 \& 1820 [2011/12 - - 2015/16], prepared by Ministry of Peace and Reconstruction, Government of Nepal, Kathmandu, 2011.

[3]. Human Trafficking Assessment Tool Report For Nepal, American Bar Association, 2011.

[4]. United Nation News Center, 2010, http://www.un.org/apps/news/search.asp.

[5]. Report of the Special Rapporteur on violence against women, Trafficking in women, women's migration and violence against women.2000, E/CN.4/2000/68

[6]. S. Huda, Sex trafficking in South Asia, International Journal of Gynecology and Obstetrics, 94, 2006, 374-381.

[7]. ONRT, Trafficking in Persons Especially on Women and Children in Nepal, National Report 2006. (Kathmandu: ONRT/NHRC, 2008).

[8]. MoWCSW, National Plan of Action on Gender Equality and Women Empowerment, Kathmandu: MOWCSW, 2004.

[9]. Harka Gurung, Nepal: Maoist Insurgency and Indigenous People, Nepali Journal of Contemporary Studies, 3, 2003,

[10]. B.R. Upreti, Armed conflict and peace process in Nepal: the maoist insurgency, past negotiations, and opportunities for conflict transformation. (New Delhi, Adroit Publisher, 2006).

[11]. A.S. Upadhyaya, Women and Peace Process in Nepal in, Priyankar Upadhyaya and Samrat Schmiem Kumar (Ed.), Peace and Conflict: the South Asian Experience, (Cambridge: Foundation Books, 2014) 140-159.

[12]. Vinod.K. Bhardwaj, Women Trafficking From Nepal in India: Uncontrolled Problem and Helpless Victims, 2011.

[13]. Bandana Shrestha, and Som Niroula, Internally Displaced Persons in Nepal, Peace and Democracy in South Asia,1(2), 2005, 44-55.

[14]. Internal Displacement Monitoring Centre, 2010, http://www.internaldisplacement.org/library/publications/2010/appeal-2010/

[15]. Internal Displacement Monitoring Centre, 2011, http://www.internaldisplacement.org/library/publications/2012/internal-displacement-global-overview-2011-peopleinternally-displaced-by-conflict-and-violence/ 
[16]. S. Gautam, A. Banskota and R. Manchanda, Where there are no men: women in the Maoist insurgency in Nepal, in Rita Manchanda (Ed.), Women, War and Peace in South Asia: Beyond Victimhood to Agency, (New Delhi: Sage, 2001) 214-251.

[17]. Y. Sangroula, Trafficking of Girls and Women in Nepal: Building a community Surveillance System for Prevention, Kathmandu School of Law, Kathmandu, Nepal, 2001.

[18]. Caritas Nepal, The Caravan of Conflict, (Kathmandu: Caritas Nepal, 2005).

[19]. Jagannath Adhikari, Poverty, Globalisation and Gendered Labour Migration in Nepal, in Sadhna Arya and Anupama Roy (Ed.), Women and Migration in Asia, (New Delhi: Sage, 2006) .

[20]. Govind Subedi, Trafficking and Sexual Abuse among Street Children in Kathmandu. ILO/IPEC Trafficking in Children South Asia-TICSA, Kathmandu, Nepal, 2002.

[21]. S.K. Joshi, Human trafficking in Nepal: A rising concern for all, Kathmandu University Medical Journal,8(29), 2010, 3-4.

[22]. Bal Kumar KC, Migration, Poverty and Development in Nepal, Asia Pacific Migration Journal,13(2), 2004, 205-232.

[23]. CWIN, Misery Behind the Looms: Child Labourers in Carpet Industry, (Kathmandu: CWIN, 1993).

[24]. CeLRRd, Analysis of Laws and Policies on Labour Migration \& Trafficking. Bhaktapur, November, 2002.

[25]. NHRC (2064BS) (2006) Annual Report 2063/064 (2005/06) (Kathmandu: National Human Rights Commission).

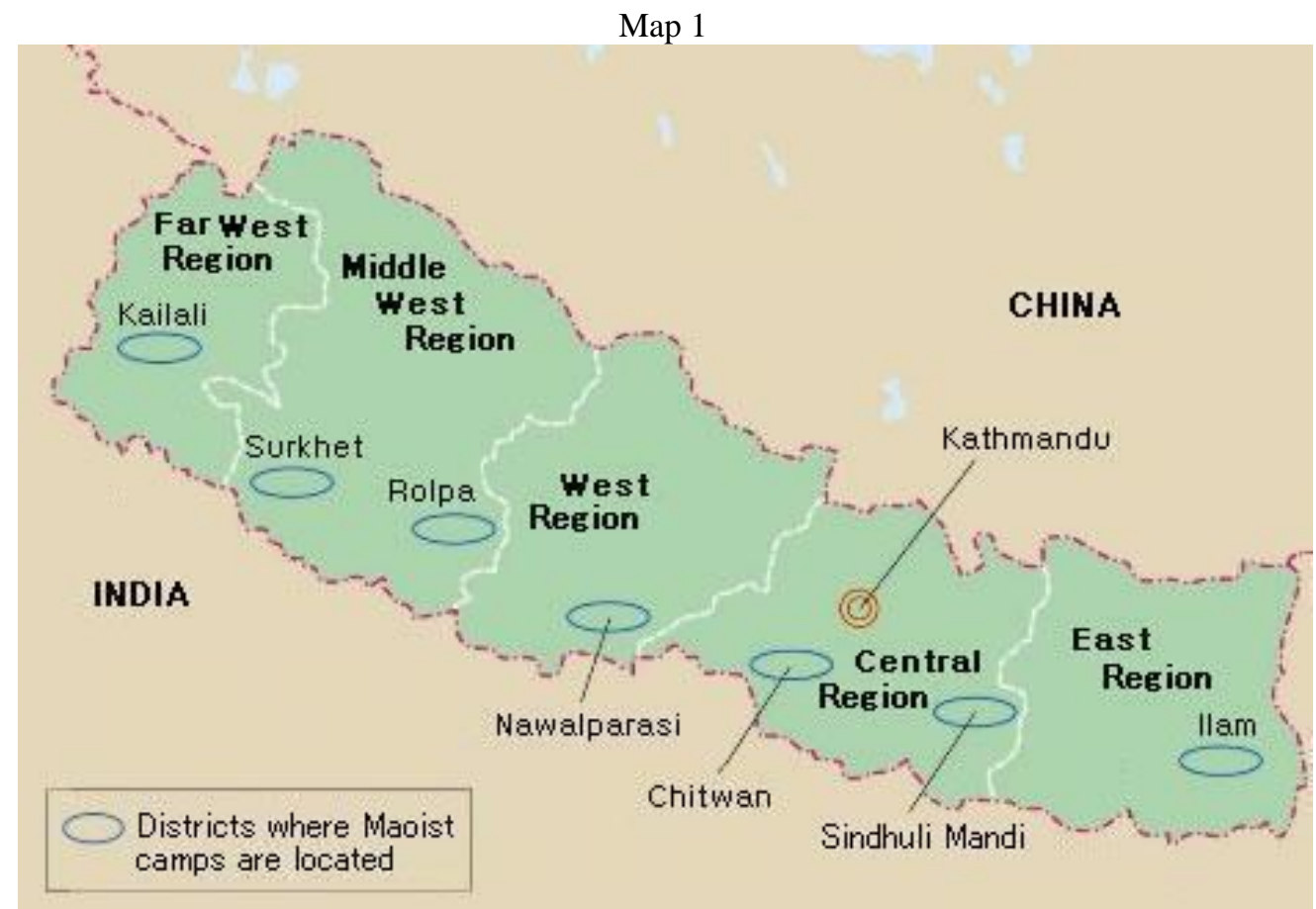

Source: www.pko.go.jp

Table-1

\begin{tabular}{|l|l|l|l|l|}
\hline Regime & Societal System & Victims & $\begin{array}{l}\text { Type of } \\
\text { Exploitation }\end{array}$ & $\begin{array}{l}\text { Type } \\
\text { Trafficking }\end{array}$ \\
\hline $\begin{array}{l}\text { Rana Regime } \\
(1847-1951)\end{array}$ & Feudal system & $\begin{array}{l}\text { Girls and } \\
\text { Women }\end{array}$ & $\begin{array}{l}\text { Slavery and Sexual } \\
\text { Exploitation }\end{array}$ & Internal \\
\hline $\begin{array}{l}\text { Post-Rana period } \\
\text { and Panchayat } \\
\text { period (1960-1990) }\end{array}$ & $\begin{array}{l}\text { Less party but } \\
\text { feudal system }\end{array}$ & $\begin{array}{l}\text { Girls and } \\
\text { Women }\end{array}$ & Sexual Exploitation & Cross-Border \\
\hline Mid 1990s-2006 & $\begin{array}{l}\text { Internal Armed } \\
\text { Conflict }\end{array}$ & $\begin{array}{l}\text { Children, } \\
\text { Girls and } \\
\text { Women }\end{array}$ & $\begin{array}{l}\text { Labour and Sexual } \\
\text { Exploitation }\end{array}$ & $\begin{array}{l}\text { Internal and } \\
\text { Cross-Border }\end{array}$ \\
\hline
\end{tabular}

Source: Nepal's National Report on Trafficking, 2006 